\title{
SRD5A2 wt Allele
}

National Cancer Institute

\section{Source}

National Cancer Institute. SRD5A2 wt Allele. NCI Thesaurus. Code C50933.

Human SRD5A2 wild-type allele is located within 2p23 and is approximately $56 \mathrm{~kb}$ in length. This allele, which encodes 3-oxo-5-alpha-steroid 4-dehydrogenase 2 protein, plays a role in the oxidation of androgens into their corresponding 5-alpha-3-oxosteroids. Specific heritable defects in the SRD5A2 gene are the cause of pseudovaginal perineoscrotal hypospadias. A specific allelic variant of this gene is associated with an increased risk of prostate cancer. 